\title{
Niepełnosprawność głosu u nauczycieli Raport z badań
}

\author{
Voice Disability in Teachers. Research Report
}

\author{
Słowa kluczowe: głos, niepełnosprawność głosowa, VHI, nauczyciele \\ Keywords: voice, voice disability, VHI, teachers
}

\section{Streszczenie}

Nauczyciele to grupa zawodowa, w której najczęściej diagnozowane są zaburzenia głosu. Niepełnosprawność głosowa może rozwijać się przez wiele lat, co utrudnia wykonywanie pracy i codzienne funkcjonowanie. W ostatnim czasie obserwuje się zarówno wzrost liczby szkoleń z profilaktyki zaburzeń głosu, jak i samych zaburzeń. Wśród 221 nauczycieli przeprowadzono badania mające na celu przedstawienie stanu niepełnosprawności głosowej w danej populacji oraz tego, ile $\mathrm{z}$ badanych osób znajduje się pod opieką foniatry. Z badań wynika, że u większości nauczycieli - 173 osób (78 proc.) - stopień niepełnosprawności głosu był niski, u 41 osób (18 proc.) średni, u 6 (3 proc.) nie występował, a u 1 osoby (1 proc.) był duży. Spośród badanych nauczycieli 62 proc. znajduje się pod stałą opieką foniatry. Najbardziej narażona chorobowo jest sfera fizyczna głosu. Nauczyciele nadużywają głosu (co widać przy subiektywnej ocenie procentowej używania głosu $-p=0,025)$. Należy podkreślić, że stanowią grupę zawodową, która potrzebuje wzmożonego wsparcia w zakresie profilaktyki opisywanego problemu.

\footnotetext{
* Uniwersytet Mikołaja Kopernika w Toruniu, Wydział Filozofii i Nauk Społecznych, Instytut Nauk Pedagogicznych, Katedra Pedagogiki Funkcjonalnej, ul. Lwowska 1, 87-100 Toruń, e-mail: hamer@ umk.pl, ORCID: https://orcid.org/0000-0002-9305-5793.
} 


\section{Abstract}

Teachers are the professional group in which voice disorders are most often diagnosed. Voice disability can develop over many years, which makes it difficult to work and function daily. Recently, there has been an increase in the number of training courses, both in the prevention of voice disorders and the disorders themselves. Research was carried out among 221 teachers to present the state of voice disability in a given population and how many of the surveyed people are under the care of a phoniatrist. The research shows that in the majority of the surveyed teachers - 173 people $(78 \%)$ - the degree of voice disability was low, in 41 people $(18 \%)$ average, in 6 people (3\%) it did not occur, and in 1 person (1\%) was large. $62 \%$ of the teachers surveyed are under the constant care of a phoniatrist. The physical sphere of the voice is the most vulnerable. Teachers abuse the voice (which can be seen at the subjective percentage price $-p=0.025$ ) and this is the cause of voice disability. Teachers are a professional group that needs increased and continuous support in the prevention of voice disorders.

\section{Wprowadzenie}

Eufonia to czysta postać głosu ludzkiego, bez jakichkolwiek poszumów i napięć w obrębie szyi, dźwięczna oraz przyjemna dla ucha odbiorcy. Głos jest ważnym instrumentem komunikacji, tworzenia i utrzymywania relacji międzyludzkich, wyrażania odczuć i emocji, a także narzędziem pracy w większości zawodów [Olszewski, Nowosielska-Grygiel, 2017]. Do jego wytwarzania niezbędne jest sprawne funkcjonowanie tzw. traktu głosowego, składającego się z narządów, które zabezpieczą przepływ strumienia powietrza wydechowego, niezbędnego do produkcji głosu (płuca, oskrzela, tchawica), wytwarzają dźwięk (krtań), formułują barwę i tworzą głoski (krtań, gardło, jama ustna, nos i zatoki przynosowe) [Śliwińska-Kowalska, Niebudek-Bogusz, 2008, s. 7].

Dysfonia to zaburzenie głosu. Choroby narządu głosu od lat zajmują trzecie miejsce wśród chorób zawodowych rejestrowanych corocznie w Polsce [Śliwińska-Kowalska i wsp., 2005; Sinkiewicz i wsp., 2021]. Największy odsetek - 66,4 proc. - zarejestrowanych chorób zawodowych narządu głosu stanowi niedowład mięśni wewnętrznych krtani z wrzecionowatą niedomykalnością fonacyjną głośni i trwałą dysfonią, 30,6 proc. przypadków to wtórne zmiany przerostowe fałdów głosowych, 2,2 proc. guzki głosowe twarde, a 0,8 proc. wtórne zmiany przerostowe fałdów głosowych z niedowładem mięśni wewnętrznych krtani z wrzecionowatą niedomykalnością fonacyjną głośni i trwałą dysfonią [Świątkowska, Hanke, Szeszenia-Dąbrowska, 2019]. Wysoka zachorowalność na dysfonię wśród nauczycieli jest odnotowywana także w innych krajach [Rosen i wsp., 2004; Thibeault i wsp., 2004]. W niniejszym artykule głos będzie opisywany z perspektywy nauczycieli, ponieważ odgrywa on znaczącą rolę w ich życiu zawodowym i właśnie w tej grupie bardzo często ulega stanom chorobowym. 
Zaburzenia głosu u nauczycieli mają w początkowym okresie charakter dysfonii czynnościowych, tzn. w narządzie głosu nie ma zmian morfologicznych, a dysfunkcja głosu jest odwracalna. Dysfonie czynnościowe są wynikiem obciążenia głosu i nieprawidłowych mechanizmów fonacyjnych z zaburzoną koordynacją oddechowo-fonacyjno-artykulacyjną. Jak zauważają Mara Behlau i współautorzy [2015], istnieje wiele predysponujących czynników i zachowań, które powodują dysfonie - między innymi podatność genetyczna, cechy psychologiczne i samozachowanie wokalne.

U osób pracujących głosem dysfonie czynnościowe prowadzą dość często do zmian organicznych fałdów głosowych, tj. guzków głosowych twardych, wtórnych zmian przerostowych fałdów głosowych oraz niedowładu mięśni krtani. Zmiany te - jako przewlekłe choroby narządu głosu, spowodowane nadmiernym wysiłkiem głosowym trwającym co najmniej 15 lat - mogą być rozpatrywane jako choroby zawodowe [Rozporządzenie Rady Ministrów z dnia 30 lipca 2002 r.]. Istnieje zatem zagrożenie, że dysfonia czynnościowa, która może być leczona prewencyjnie i poprzez rehabilitację, przeobrazi się w dysfonię organiczną, co często wiąże się już z leczeniem chirurgicznym.

Najczęściej spotykanymi objawami dysfonii u nauczycieli są: parestezje gardła i krtani, nawykowe chrząkanie, zmatowienie głosu, zawężenie skali głosu, okresowe zaniki głosu, utrwalona chrypka z bezgłosem, męczliwość głosu czy ból w okolicy gardła i krtani podczas mówienia (odynofonia) [Niebudek-Bogusz i wsp., 2007].

Ocena zaburzeń głosu powinna być wielowymiarowa. Oprócz badania klinicznego bardzo ważne są analizy słuchowo-percepcyjne, akustyczne i samoocena [Behlau i wsp., 2015]. Celem niniejszego artykułu jest przedstawienie wyników badań prowadzonych nad niepełnosprawnością głosu u nauczycieli, w których wykorzystano kwestionariusz do badania samooceny niepełnosprawności głosu Voice Handicap Index (VHI). Opiera się on na samoocenie głosu dokonywanej przez osoby badane i dotyczy zaburzeń głosu z perspektywy trzech sfer, które obejmują różne dolegliwości głosowe:

1) sfery funkcjonalnej, opisującej wpływ zaburzeń głosu na codzienną aktywność społeczno-zawodową;

2) sfery emocjonalnej, opisującej wpływ zaburzeń głosu na odczucia chorego w stosunku do własnego głosu;

3) sfery fizycznej, dotyczącej odczuwanych dolegliwości fizycznych związanych $\mathrm{z}$ chorobą narządu głosu.

Kwestionariusz łącznie zawiera 30 pytań. Po raz pierwszy został on wprowadzony przez Barbarę H. Jacobson i współautorów w 1997 roku [2016], a na język polski przetłumaczył go w 2003 roku Antoni Pruszewicz i współautorzy, walidacji dokonała natomiast Ewa Niebudek-Bogusz i współautorzy w 2007 roku. 


\section{Niepełnosprawność głosu u nauczycieli - metodologia badań własnych}

Przedmiotem prowadzonych badań była niepełnosprawność głosu u nauczycieli, a celem eksploracyjnym opisanie tej niepełnosprawności. Postawiono następujące pytania badawcze:

1. Czy u badanych nauczycieli występuje niepełnosprawność głosowa?

2. Która ze sfer niepełnosprawności głosowej jest najbardziej zaburzona u badanych nauczycieli?

3. Ilu spośród badanych nauczycieli znajduje się pod opieką foniatry?

4. Jaka jest najczęściej występująca przyczyna konsultacji foniatrycznych badanych nauczycieli?

5. Jaki jest związek pomiędzy wiekiem, stażem pracy, tygodniowym pensum dydaktycznym oraz subiektywną oceną procentowego używania głosu w pracy a występowaniem niepełnosprawności głosowej u badanych nauczycieli?

6. Czy liczba miejsc pracy różnicuje niepełnosprawność głosową u badanych nauczycieli?

Zmiennymi niezależnymi były: wiek, staż pracy, liczba miejsc pracy, tygodniowe pensum dydaktyczne, subiektywna ocena procentowego używania głosu w pracy. Zmiennymi zależnymi były: niepełnosprawność głosu oraz jej wskaźniki - sfera funkcjonalna, sfera emocjonalna i sfera fizyczna.

Przeprowadzono badania ilościowe $\mathrm{z}$ wykorzystaniem metody sondażu diagnostycznego. Zastosowano technikę ankiety, a narzędziem był kwestionariusz niepełnosprawności głosu Voice Handicap Index (VHI).

Podczas badania respondenci przy każdy zdaniu wskazywali jedną z pięciu podanych odpowiedzi, które były punktowane w skali od 0 do 4 , przy czym odpowiedź „nigdy” to 0 punktów, „prawie nigdy” - 1, „czasami” - 2, „prawie zawsze” - 3, a „zawsze" - 4 punkty. Całkowity wynik VHI określa stopień zaburzeń głosu. Uzyskanie 0 punktów określa brak niepełnosprawności głosu, punktacja od 1 do 30 określana jest jako niewielki stopień niesprawności głosu, 31-60 punktów to średni stopień niesprawności głosu, natomiast wynik powyżej 61 punktów oznacza duży stopień niesprawność głosu.

W badaniach wzięło udział 221 nauczycieli. Ankietowani wyrazili zgodę na udział w badaniach. Mieli świadomość, że w każdym momencie badania mogą zrezygnować z udziału bez podawania przyczyny.

Respondenci byli w wieku od 24 do 62 lat, średnia wieku wyniosła 41 lat, odchylenie standardowe 9,2. Wśród badanych było 18 mężczyzn i 203 kobiety. Staż pracy badanych nauczycieli wynosił średnio 17 lat, odchylenie standardowe 10,08. Najkrótszy staż pracy wynosił rok, a najdłuższy 37 lat. Większość badanych pracowała w jednym miejscu - 163 osoby, dwa miejsca pracy miało 51 osób, trzy - 6 osób, jedna osoba zadeklarowała, że pracuje w czterech miejscach. Średnie pensum dydaktyczne 
wynosiło 24 godziny pracy tygodniowo. Średni wynik subiektywnej oceny procentowego używania głosu w pracy wyniósł 78 proc.

Do analizy wyników badań zastosowano program Statistica 1.3.1.

\section{Wyniki badań własnych}

Na początek przeprowadzono statystyki opisowe dla zmiennej zależnej - niepełnosprawność głosowa i jej poszczególnych sfer. Średni wynik niepełnosprawności głosu w badanej grupie wyniósł 17,95 (min. 0 pkt, a maks. 75 pkt). Najwyższy średni wynik dotyczący poszczególnych sfer niepełnosprawności głosu był w sferze fizycznej - 8,67, następnie w sferze funkcjonalnej - 5,21 i na koniec w sferze emocjonalnej $-4,06$ (tabela 1).

Tabela 1. Statystyki opisowe dla zmiennych zależnych

\begin{tabular}{|l|c|c|c|c|c|}
\hline \multicolumn{1}{|c|}{ Zmienna } & N ważnych & Średnia & Min. & Maks. & Odch. stand. \\
\hline $\begin{array}{l}\text { Niepełnosprawność } \\
\text { głosowa }\end{array}$ & 221 & 17,95 & 0 & 75 & 14,37 \\
\hline Sfera funkcjonalna & 221 & 5,21 & 0 & 20 & 4,16 \\
\hline Sfera emocjonalna & 221 & 4,06 & 0 & 25 & 4,97 \\
\hline Sfera fizyczna & 221 & 8,67 & 0 & 32 & 6,95 \\
\hline
\end{tabular}

Źródło: opracowanie własne.

Dalsza analiza pozwoliła ustalić, jaki jest stopień niepełnosprawności głosu wśród badanych nauczycieli (wykres 1).

Niepełnosprawność głosu w ocenie nauczycieli

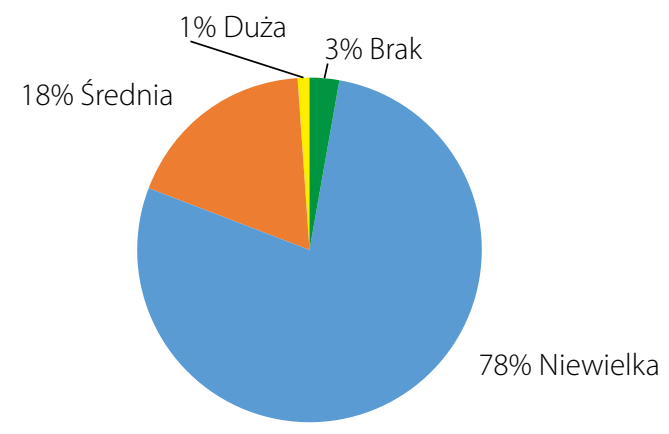

Wykres 1. Niepełnosprawność głosu u nauczycieli

Źródło: opracowanie własne. 
U większości badanych nauczycieli - 173 osób (78 proc.) - stopień niepełnosprawności głosu był niski, u 41 osób (18 proc.) średni, u 6 (3 proc.) nie występował, a u 1 osoby (1 proc.) był duży (tabela 2 ).

Tabela 2. Stopień niepełnosprawności głosowej u badanych nauczycieli

\begin{tabular}{|c|c|c|c|c|}
\hline $\begin{array}{c}\text { Stopień niepełnosprawności } \\
\text { głosowej }\end{array}$ & $\begin{array}{c}\text { Brak } \\
0 \mathrm{pkt}\end{array}$ & $\begin{array}{c}\text { Niski } \\
1-30 \mathrm{pkt}\end{array}$ & $\begin{array}{c}\text { Średni } \\
31-60 \mathrm{pkt}\end{array}$ & $\begin{array}{c}\text { Duży } \\
\text { więcej niż } \\
60 \mathrm{pkt}\end{array}$ \\
\hline Liczba osób (proc.) & 6 (3 proc.) & 173 (78 proc.) & 41 (18 proc.) & 1 (1 proc.) \\
\hline
\end{tabular}

Źródło: opracowanie własne.

Nauczyciele mają trudności z głosem w sferze fizycznej. W tym obszarze 55 osób (25 proc.) uzyskało średni stopień niepełnosprawności głosu (tabela 3). Ponadto na podstawie analizy wyników badań okazało się, że u 187 badanych nauczycieli (85 proc.) występował niski stopień niepełnosprawności głosu w sferze funkcjonalnej, a u 144 (65 proc.) taki sam poziom był w sferze fizycznej. Podobnie było w sferze emocjonalnej - 135 osób (61 proc.) miało niski poziom niepełnosprawności głosowej.

Tabela 3. Poziom zaburzenia poszczególnych sfer niepełnosprawności głosu u nauczycieli

\begin{tabular}{|c|c|c|c|c|}
\hline $\begin{array}{c}\text { Sfera niepełnosprawności } \\
\text { głosu }\end{array}$ & $\begin{array}{c}\text { Brak zaburzenia } \\
0 \text { pkt }\end{array}$ & $\begin{array}{c}\text { Niski poziom } \\
\text { zaburzenia } \\
1-13 \text { pkt }\end{array}$ & $\begin{array}{c}\text { Średni poziom } \\
\text { zaburzenia } \\
14-26 \text { pkt }\end{array}$ & $\begin{array}{c}\text { Duży poziom } \\
\text { zaburzenia } \\
27-40 \text { pkt }\end{array}$ \\
\hline Funkcjonalna & 24 (11 proc.) & 187 (85 proc.) & 10 (4 proc.) & 0 (0 proc.) \\
\hline Emocjonalna & 74 (34 proc.) & 135 (61 proc.) & 12 (5 proc.) & 0 (0 proc.) \\
\hline Fizyczna & 21 (9 proc.) & 144 (65 proc.) & 55 (25 proc.) & 1 (1 proc.) \\
\hline
\end{tabular}

Źródło: opracowanie własne.

Spośród badanych nauczycieli 137 osób (62 proc.) znajdowało się pod opieką foniatry, a 84 osoby (38 proc.) przyznały, że nie korzystały z konsultacji tego specjalisty. Według nauczycieli powody wizyt u foniatry były różnorodne: badania kontrolne (40 osób), chrypa (30 osób), bezgłos (18 osób), zapalenie krtani (17 osób), zapalenie gardła ( 7 osób), problem z głosem (6 osób), zapalenie ucha (4 osoby), suchość (3 osoby), inne (6 osób) (wykres 2).

Następnie za pomocą regresji wielorakiej sprawdzono związek pomiędzy wiekiem, stażem pracy, tygodniową liczbą godzin pracy oraz subiektywną oceną procentowego używania głosu w pracy a niepełnosprawnością oraz jej poszczególnymi sferami u badanych nauczycieli. Okazało się, że istnieje istotny statystycznie związek pomiędzy wiekiem oraz subiektywną oceną procentowego używania głosu w pracy a sferą funkcjonalną niepełnosprawności głosowej (tabela 4). 


\section{Przyczyny wizyt u foniatry z relacji nauczycieli}

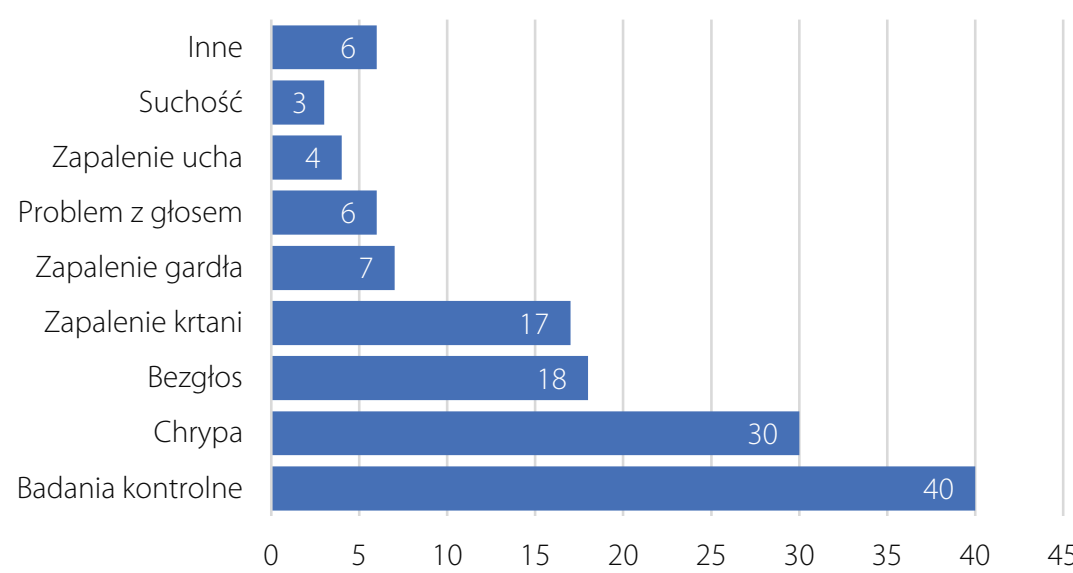

Wykres 2. Przyczyny wizyt u foniatry z relacji nauczycieli

Źródło: opracowanie własne.

Tabela 4. Wiek i procentowe używanie głosu a sfera funkcjonalna - regresja wieloraka

\begin{tabular}{|l|c|c|c|c|c|c|}
\hline $\begin{array}{c}\text { Zmienna niezależna/zmien- } \\
\text { na zależna }\end{array}$ & $\boldsymbol{R}$ & $\boldsymbol{F}$ & $\boldsymbol{t}$ & $\boldsymbol{p}$ & $\boldsymbol{b}^{*}$ & $\begin{array}{c}\text { Błąd } \\
\text { stand. }\end{array}$ \\
\hline Wiek/sfera funkcjonalna & 0,213 & 10,349 & 3,22 & $0,00149^{*}$ & 0,213 & 1,25 \\
\hline $\begin{array}{l}\text { Proc. używanie głosu/sfera } \\
\text { funkcjonalna }\end{array}$ & 0,155 & 2,549 & $-2,252$ & $0,025^{*}$ & $-0,156$ & 0,01 \\
\hline
\end{tabular}

${ }^{*} p<0,05$ - wynik istotny statystycznie.

\section{Źródło: opracowanie własne.}

Wynik regresji wielorakiej dla wieku i sfery funkcjonalnej niepełnosprawności głosu wyniósł $R=0,213, \mathrm{~F}=10,34, p=0,00149$, z kolei dla subiektywnej oceny procentowego używania głosu w pracy a tej samej sfery osiągnął wartość $R=0,155, F=2,549$, $p=0,025$. Wyniki tej regresji wskazują, że spośród wszystkich czynników (wiek, staż pracy, pensum dydaktyczne, subiektywna ocena procentowego używania głosu w pracy) to właśnie wiek w największym stopniu mógł przyczyniać się do powstawania niepełnosprawności głosowej w sferze funkcjonalnej u badanych nauczycieli.

Przeprowadzono także macierz korelacji i ponownie uzyskano istotne statystycznie wyniki dla dwóch zmiennych: subiektywnej oceny procentowego używania głosu w pracy oraz stanu funkcjonalnego niepełnosprawności głosu. Korelacja wyniosła $p=-0,152$.

Wykorzystano również korelację rang Spearmana, która ponownie potwierdziła istnienie związku między wiekiem a niepełnosprawnością głosową i jej wszystkimi sferami oraz związku między subiektywną oceną procentowego używania głosu w pracy a sferą funkcjonalną i emocjonalną niepełnosprawności głosu (tabela 5). 
Tabela 5. Korelacja rang Spearmana

\begin{tabular}{|l|c|c|c|c|}
\hline $\begin{array}{c}\text { Niepełnosprawność gło- } \\
\text { su i jej rodzaj względem } \\
\text { zmiennej niezależnej }\end{array}$ & $\begin{array}{c}\text { Liczba godzin } \\
\text { pracy }\end{array}$ & Wiek & $\begin{array}{c}\text { Liczba miejsc } \\
\text { pracy }\end{array}$ & $\begin{array}{c}\text { Proc. używanie } \\
\text { głosu w pracy }\end{array}$ \\
\hline Niepełnosprawność głosu & 0,086 & $0,207^{*}$ & $-0,032$ & $-0,113$ \\
\hline Stan funkcjonalny & 0,020 & $0,203^{*}$ & $-0,046$ & $-0,164^{*}$ \\
\hline Stan emocjonalny & 0,078 & $0,226^{*}$ & $-0,027$ & $-0,137^{*}$ \\
\hline Stan fizyczny & 0,109 & $0,154^{*}$ & $-0,048$ & $-0,051$ \\
\hline
\end{tabular}

${ }^{*} p<, 0500$.

\section{Źródło: opracowanie własne.}

Wyniki korelacji rang Spearmana także potwierdzają, że to właśnie wiek i subiektywna ocena procentowego używania głosu w pracy mogły przyczyniać się do powstawania niepełnosprawności głosowej u nauczycieli.

\section{Dyskusja}

Wskaźnik niepełnosprawności głosu (VHI) jest jednym z najczęściej stosowanych narzędzi do pomiaru samooceny nasilenia głosu przez pacjenta. Pod pewnymi względami odzwierciedla on jakość życia pacjenta. Kwestionariusz jest przede wszystkim rozpoznawany i szeroko stosowany w populacjach w krajach europejskich i populacjach anglojęzycznych [Malki i wsp., 2010]. W Polsce jest on także szeroko wykorzystywanym testem. Niebudek-Bogusz i współautorzy [2007] zastosowali go w badaniach oceny efektywności terapii głosu u nauczycieli. Różnice w średnich wynikach VHI uzyskanych przed leczeniem foniatrycznym i po nim były znacznie większe wśród nauczycieli rehabilitowanych (grupa I) niż wśród nierehabilitowanych (grupa II) $(p<0,05)$. Ponadto w grupie I poprawa po leczeniu dotyczyła wszystkich podskal (funkcjonalnej, emocjonalnej i fizycznej), natomiast w grupie II tylko podskali fizycznej.

Jak podaje Anna Sinkiewicz i współautorzy [2021], uwzględnienie w procesie rehabilitacji czynników usposabiających do zmian przeciążeniowych głosu jest bardzo istotne w perspektywie dalszej pracy głosem - między innymi przez nauczycieli. Zawodowe zaburzenia głosu są skutkiem nie tylko jego przeciążenia, ale także są związane ze środowiskiem pracy, ogólnym stanem zdrowia oraz czynnikami socjodemograficznymi, a także psychologicznymi.

W prezentowanych badaniach wykazano, że wiek oraz procentowa wartość używania głosu w pracy mają znaczenie w powstawaniu niepełnosprawności głosowej. Potwierdzają to także badania Sinkiewicz i współautorów [2021] - zauważono w nich, że osoby z najdłuższym stażem mają mniejsze możliwości osiągnięcia zadowalających efektów rehabilitacji głosu. Powodem mogły być zmiany związane $\mathrm{z}$ wiekiem. Ponadto nauczyciele powyżej 50. roku życia w znacznie 
mniejszym stopniu niż nauczyciele w młodszych grupach wiekowych przestrzegali zasad emisji i higieny głosu [Sinkiewicz i wsp., 2021].

Mimo, że w prezentowanej analizie nie wykazano istotnego związku między stażem pracy a niepełnosprawnością głosową wśród badanych nauczycieli, warto zwrócić uwagę na to, iż taka korelacja zaistniała w innych badaniach. Jak wykazuje Magdalena Rzepa [2010], choroby narządu głosu pojawiają się wraz ze wzrostem liczby lat pracy. Pierwsza fala zachorowań występuje po drugim roku pracy, kiedy warunki głosowe nauczyciela nie mogą sprostać stawianym im wymaganiom i ustawicznemu obciążeniu, do jakiego wcześniej nie były przygotowane. Następnie najbardziej narażona jest grupa $\mathrm{z}$ dziesięcioletnim stażem pracy, ponieważ wcześniejsze, nieleczone niedomagania nakładają się na nowo tworzone.

Leczenie i rehabilitacja $\mathrm{w}$ formie stacjonarnej powinny zmierzać do poprawy głosu oraz kontynuacji pracy zawodowej [Sinkiewicz i wsp., 2021]. Warto zastanowić się nad wprowadzeniem systematycznej opieki foniatrycznej nad nauczycielami. Ponadto należy rozwijać wczesną interwencję logopedyczną z zakresu rehabilitacji zaburzeń głosu.

\section{Wnioski}

1. Z uwagi na duże obciążenie zawodowe wskazane jest, aby nauczyciele znajdowali się pod stałą, obowiązkową i częstą kontrolą foniatryczną oraz logopedyczną.

2. Wraz z wiekiem problemy głosowe nauczycieli się zwiększają.

3. Istnieje związek między subiektywną procentową oceną używania głosu przez nauczycieli w pracy a występowaniem niepełnosprawności głosowej. Sugeruje to wprowadzenie modyfikacji w życiu zawodowym, tak aby głos był mniej obciążany.

4. Z uwagi na predyspozycje do niesprawności głosowej warto zachęcać nauczycieli do systematycznego uczestnictwa w szkoleniach z zakresu prawidłowej emisji głosu.

\section{Literatura}

Behlau M., Madazio G., Moreti F., Oliveira G., Alves dos Santos L., Paulinelli B., Couto Junior E., 2015, Efficiency and Cutoff Values of Self-Assessment Instruments on the Impact of a Voice Problem, „Journal of Voice: Official Journal of the Voice Foundation”, vol. 30, s. 110.

Jacobson B., Johnson A., Grywalski C., Silbergleit A., Jacobson G., Benninger M., Newman C., 2016, The Voice Handicap Index (VHI): development and validation, „American Journal of SpeechLanguage Pathology", no. 6, s. 66-70. 
Malki K., Mesallam T., Farahat M., Bukhari M., Murry T., 2010, Validation and cultural modification of Arabic voice handicap index, „European Archives of Oto-Rhino-Laryngology”, vol. 267(11), s. 1743-1751.

Niebudek-Bogusz E., Kuzańska A., Błoch P., Domańska M., Woźnicka E., Politański P., Śliwińska-Kowalska M., 2007, Zastosowanie wskaźnika niepelnosprawności głosowej (Voice Handicap Index - VHI) w ocenie efektywnej terapii głosu u nauczycieli, „Medycyna Pracy”, nr 58(6), s. 1-9.

Olszewski J., Nowosielska-Grygiel J., 2017, Nowe metody diagnostyczne oceny czynności głosu dla potrzeb foniatry i logopedy, „Logopaedica Lodziensia”, nr 1, s. 91-99.

Pruszewicz A., Obrebowski A., Wiskirska-Woźnica B., Wojnowski W., 2003, Complex voice assessment - Polish version of the Voice Handicap Index (VHI), „Otolaryngologia Polska”, nr 58(3), s. 547-549.

Rosen C., Lee A., Osborne J., Zullo T., Murry T., 2004, Development and validation of the voice handicap index-10, „Laryngoscope”, vol. 114(9), s. 1549-1556.

Rozporządzenie Rady Ministrów z dnia 30 lipca 2002 r. w sprawie wykazu chorób zawodowych, szczegółowych zasad postępowania w sprawach zgłaszania podejrzenia, rozpoznawania i stwierdzenia chorób zawodowych oraz podmiotów właściwych w tych sprawach (Dz.U. z 2002 r. Nr 132, poz. 1115).

Rzepa M., 2010, Choroby zawodowe narządu głosu wśród nauczycieli, „Nauczyciel i Szkoła”, nr 3(48), s. 141-153.

Sinkiewicz A., Garstecka A., Mackiewicz-Nartowicz H., Nawrocka L., Wojciechowska W., Szkiełkowska A., 2021, Sanatoryjna rehabilitacja głosu u nauczycieli, „Medycyna Pracy”, nr 72(4), s. 1-7.

Śliwińska-Kowalska M., Niebudek-Bogusz E., 2008, Rehabilitacja zawodowych zaburzeń głosu. Poradnik dla nauczycieli, Instytut Medycyny Pracy im. Prof. J. Noffera, Łódź.

Śliwińska-Kowalska M., Niebudek-Bogusz E., Fiszer M., Łoś-Spychalska T., Kotyło P., Sznurowska-Przygocka B., Modrzewska M., 2005, The prevalence and risk factors for occupational voice disorders in teachers, „Folia Phoniatrica et Logopaedica”, vol. 58(2), s. 85-101.

Świątkowska B., Hanke W., Szeszenia-Dąbrowska N., 2019, Choroby zawodowe w Polsce w 2019 roku, Instytut Medycyny Pracy im. Prof. J. Noffera, Centralny Rejestr Chorób Zawodowych, Łódź 2020, http://www.imp.lodz.pl/upload/choroby_zawodowe/2020/chorobyza wodowe_2019_19.06_final_na_str_imp.pdf (dostęp: 1.01.2021).

Thibeault S., Merril R., Roy N., Gray S., Smith E., 2004, Occupational risk factors associated with voice disorders among teachers, „Annals of Epidemiology”, vol. 14(10), s. 786-792.

\begin{tabular}{|l|l|}
\hline CC & $\begin{array}{l}\text { (c) by the author, licensee Łódź University - Łódź University Press, tódź, Poland. } \\
\text { This article is an open access article distributed under the terms and conditions } \\
\text { of the Creative Commons Attribution license CC-BY-NC-ND } 4.0 \\
\text { (https://creativecommons.org/licenses/by-nc-nd/4.0/) }\end{array}$ \\
\cline { 2 - 2 } & Data złożenia: 6.08.2021. Data przyjęcia: 27.10 .2021$.
\end{tabular}

